\title{
ANALISIS PENGARUH WHOLE BODY VIBRATION (WBV) TERHADAP KELUHAN LOW BACK PAIN (LBP) PADA OPERATOR ALAT BERAT DI PT. $X$
}

\author{
Halisa Kurniati ${ }^{1}$, Rostika Flora ${ }^{2}$, Rico Januar Sitorus ${ }^{3}$ \\ ${ }^{1}$ Departemen Kesehatan Keselamatan Kerja Fakultas Kesehatan Masyarakat \\ Universitas Sriwijaya \\ ${ }^{2}$ Departemen Gizi Fakultas Kesehatan Masyarakat Universitas Sriwijaya \\ ${ }^{3}$ Departemen Epidemiologi dan Biostatistik Fakultas Kesehatan Masyarakat \\ Universitas Sriwijaya \\ halisa_kurniati@yahoo.com ${ }^{1}$,rostikaflora@gmail.com ${ }^{2}$,rico_januar@fkm.unsri.ac.id ${ }^{3}$
}

\begin{abstract}
Low back pain is a common disease affecting almost all individuals at some point in their life. Low back pain is multifactorial in origin. The cause of increased prevalence of low back pain in populations of professional drivers is often uncertain. The factor reported to be most strongly associated with low back pain are exposure to whole body vibration. Other possible risk factors with weaker or inconsistenst evidence for influencing low back pain are individual factors (age, time of work, body mass index and physical activitity). Methods: This research is conducted observasionally with cross sectional design with a large sample of 70 people which selected by purposive sampling. Data collected from accelerometer, questionnaires, observation and interviews. Result: The results of research obtained that exposure whole body vibration suffered by operator is $0,543 \mathrm{~m} / \mathrm{s}^{2}$ and complaints of low back pain on a heavy equipment operators at PT. $X$ is $64,3 \%$. Bivariat analysis showed that there are significant relationship between whole body vibration ( $p<0,05 ; 95 \%$ CI 0,99-2,99 OR 1,723), age ( $p<0,05 ; 95 \%$ CI 1,42-3,77 OR 2,31), time of work ( $p<0,05$; $95 \%$ CI 1,07-7,81 OR 2,89) with low back pain. There was no significant relationship between body mass index ( $p>0,05 ; 95 \%$ CI 0,68-1,37 OR 0,969) and physical activity ( $p>0,05 ; 95 \%$ CI 0,55-1,14 OR 0,798) to low back pain. This research conclude that there is correlation whole body vibration with complaints of low back pain.
\end{abstract}

Keywords: whole body vibration, low back pain, operator

\section{PENDAHULUAN}

Salah satu gangguan musculoskeletal disorders (MSDs) adalah low back pain (LBP). Pada umumnya low back pain (LBP) merupakan salah satu masalah medis dan sosial ekonomi yang paling signifikan dalam masyarakat modern (Thomas et al., 2010). Pada tahun 2007, 25 $\%$ pekerja dari 27 negara anggota Uni Eropa mengalami keluhan low back pain (LBP) (OSHA, 2007). Tingginya angka prevalensi low back pain (LBP) yaitu 
sebesar $15 \%$ - 84\% dapat mengakibatkan pekerja kehilangan hari kerja, penurunan produktifitas kerja dan kerugian ekonomi yang signifikan sehingga mempengaruhi masyarakat dan ekonomi negara tersebut (Janwantanakul et al., 2008; Mitchell et al., 2008; Monteiro et al., 2009).

Studi Global Burden of Disease pada tahun 2010 melaporkan bahwa low back pain (LBP) menyebabkan lebih banyak kecacatan dan dinyatakan sebagai years lived with disability (YLDs). Diperkirakan bahwa YLDs dari LBP telah meningkat dari 58,2 juta pada tahun 1990 menjadi 83,0 juta pada tahun 2010 diseluruh dunia $(32,40)$ (Bovenzi, Schust and Mauro, 2017). Berdasarkan data dari Labour Force Survey (LFS) U.K, pekerja yang mengalami ganguaan low back pain (LBP) di tahun 2016/2017 adalah 590 kasus per 100.000 pekerja. Ini setara dengan 194.000 total kasus di tahun2016/2017 (Health and Safety Executive, 2017).

Hasil Riset Kesehatan Dasar tahun 2013 menunjukkan bahwa prevalensi penyakit musculoskeletal di Indonesia berdasarkan hasil diagnosis oleh tenaga kesehatan yaitu 11,9 persen dan berdasarkan diagnosis atau gejala yaitu 24,7 persen. Sedangkan di Provinsi Jakarta angka prevalensi penyakit musculoskeletal berdasarkan diagnosis dan gejala yaitu 15,6 persen. Prevalensi penyakit musculoskeletal tertinggi berdasarkan pekerjaan adalah pada petani, nelayan atau buruh yaitu 31,2 persen (Riskesdas, 2013).

Low back pain (LBP) paling sering terjadi didalam industri kerja. Industri dengan angka kejadian MSDs tertinggi selama tiga periode yaitu pada tahun 2014/2015-2016/2017 adalah pertanian, kehutanan, perikanan, transportasi dan konstruksi (Health and Safety Executive, 2017). Paparan whole body vibration (WBV) yang dapat diterima adalah 0,5 $\mathrm{m} / \mathrm{s}^{2} \mathrm{~A}(8)$. Kombinasi antara Whole body vibration (WBV) dan postur kerja yang janggal dapat mengakibatkan risiko cedera muskuloskeletal yang berlebihan dan gangguan pada punggung bagian bawah (Kittusamy and Buchholz, 2004; Tüchsen et al., 2010; COWI, 2015).

PT. X merupakan salah satu perusahaan yang bergerak di bidang industri pondasi di Indonesia khususnya di Jakarta Utara. PT. X memfokuskan kegiatan usahanya pada pembuatan pondasi, dinding penahan tanah dan perbaikan tanah. Berdasarkan studi pendahuluan yang penulis lakukan di PT. $\mathrm{X}$, operator alat berat bekerja dalam posisi statis dengan postur janggal serta terpapar 
whole body vibration (WBV) dalam jangka waktu yang lama dan diketahui bahwa hampir seluruh pekerja mengeluhkan sakit dan pegal-pegal pada bagian tubuh. Maka perlu dilakukan penelitian lebih lanjut untuk menganalisis pengaruh whole body vibration (WBV) terhadap keluhan low back pain (LBP) pada pekerja operator alat berat di PT.X.

\section{METODE PENELITIAN}

Penelitian ini merupakan penelitian observasional analitik dengan pendekatan cross-sectional. Desain ini merupakan model pendekatan yang menggunakan satu kali pengumpulan data pada waktu yang sama, dimana pengambilan data menyangkut variabel dependen yaitu keluhan low back pain (LBP) dan variabel independen yaitu whole body vibration (WBV), umur, masa kerja, indeks massa tubuh dan aktifitas fisik.

Teknik pengambilan sampel dalam penelitian ini menggunakan metode non probability sampling dengan teknik purposive sampling. Analisis univariat untuk menentukan distribusi dan frekuensi variabel dependen dan variabel independen, analisis bivariat dengan uji statistik chi-square dengan batas kemaknaan $\mathrm{p}<\alpha(\alpha=0,05)$ dan analisis multivariat dengan uji statistik regresi logistik ganda. Data yang dianalisis kemudian disajikan dalam bentuk tabel dan narasi untuk membahas hasil penelitian

\section{HASIL PENELITIAN}

\section{Analisis Univariat}

Tabel 1 Distribusi Frekuensi Responden Berdasarkan Keluhan Low Back Pain (LBP) pada Operator Alat Berat di PT. X

\begin{tabular}{ccc}
\hline $\begin{array}{c}\text { Keluhan Low } \\
\text { Back Pain }(\text { LBP) }\end{array}$ & N & \% \\
\hline Ada keluhan & 45 & 64,3 \\
Tidak ada keluhan & 25 & 35,7 \\
\hline Total & $\mathbf{7 0}$ & $\mathbf{1 0 0}$ \\
\hline
\end{tabular}

Berdasarkan Tabel 1 dapat dilihat bahwa distribusi responden terbanyak adalah ada keluhan low back pain (LBP) pada operator alat berat di PT. X sebesar $45(64,3 \%)$ dan angka tidak ada keluhan low back pain (LBP) pada operator alat berat di PT.X sebesar $25(35,7 \%)$ dari total 70 responden.

Tabel 2 Distribusi Besar Intensitas Whole Body Vibration (WBV) pada Operator Alat Berat di PT. X

\begin{tabular}{cccc}
\hline Variabel & Min-Max & Mean & Median \\
\hline $\begin{array}{c}\text { Whole body } \\
\text { vibration } \\
\text { (WBV) }\end{array}$ & $\begin{array}{c}0,043- \\
1,450\end{array}$ & 0,543 & 0,524 \\
\hline
\end{tabular}

Berdasarkan Tabel 2 didapatkan rata-rata besar intensitas whole body vibration $\left(\mathrm{WBV}\right.$ ) adalah $0,543 \mathrm{~m} / \mathrm{s}^{2}$. Nilai intensitas whole body vibration (WBV) terendah adalah $0,043 \mathrm{~m} / \mathrm{s}^{2}$ dan nilai 
intensitas whole body vibration (WBV) tertinggi adalah $1,450 \mathrm{~m} / \mathrm{s}^{2}$.

Tabel 3 Distribusi Frekuensi Whole Body Vibration (WBV) pada Operator Alat Berat di PT X

\begin{tabular}{ccc}
\hline $\begin{array}{c}\text { Whole Body Vibration } \\
\text { (WBV) }\end{array}$ & $\mathbf{n}$ & $\mathbf{\%}$ \\
\hline > NAB & 19 & 27,1 \\
< NAB & 51 & 72,9 \\
\hline Total & $\mathbf{7 0}$ & $\mathbf{1 0 0}$ \\
\hline
\end{tabular}

Berdasarkan Tabel 3 dapat dilihat distribusi whole body vibration (WBV) pada operator alat berat di PT. X terbanyak dengan kategori $\leq \mathrm{NAB}$ sebesar 51 $(72,9 \%)$ dan whole body vibration (WBV) dengan kategori > NAB sebesar 19 $(27,1 \%)$.

Tabel 4 Karakteristik Responden Penelitian

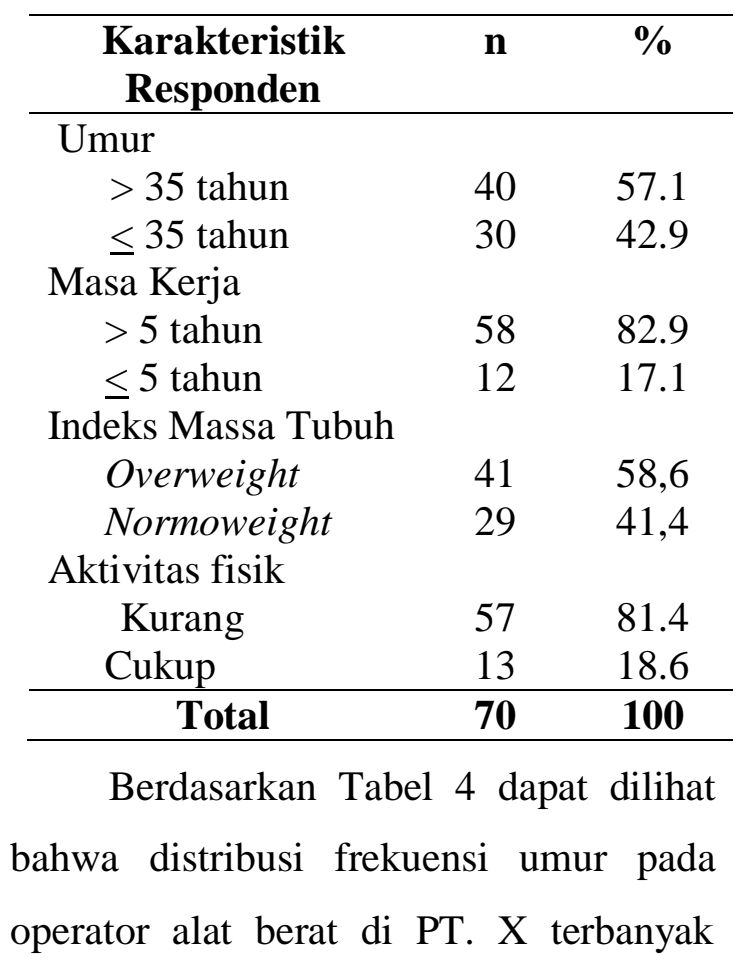

dengan kategori > 35 tahun sebesar 40 $(57.1 \%)$ dan dengan kategori $\leq 35$ tahun pada operator alat berat di PT.X sebesar 30 $(42.9 \%)$ dari total 70 responden. Distribusi frekuensi masa kerja pada operator alat berat di PT. X terbanyak dengan kategori $>5$ tahun sebesar 58 (82.9\%) dan dengan kategori $\leq 5$ tahun sebesar $12(17.1 \%)$. Distribusi frekuensi indeks massa tubuh pada operator alat berat di PT. X terbanyak pada kategori overweight (>23) sebesar 41 $(58.6 \%)$ dan dengan kategori normal (18.5-22.9) sebesar 29 (41,4\%). Distribusi frekuensi aktivitas fisik pada operator alat berat di PT. X terbanyak dengan kategori kurang (<150 menit/minggu) sebesar 57 $(81.4 \%)$ dan dengan kategori cukup $(\geq$ 150 menit/minggu ) sebesar 13 (18.6\%).

\section{Analisis Bivariat}

Analisis dilakukan untuk melihat hubungan antara variabel independen dengan variabel dependen. Uji yang digunakan dengan menggunakan uji chisquare. 
Tabel 5 Hubungan Whole Body Vibration (WBV) dengan Keluhan Low Back Pain (LBP) pada Operator Alat Berat di PT. X

\begin{tabular}{|c|c|c|c|c|c|c|c|}
\hline \multirow{3}{*}{$\begin{array}{c}\text { Whole Body } \\
\text { Vibration }\end{array}$} & \multicolumn{4}{|c|}{ Keluhan Low Back Pain } & \multirow{3}{*}{$\begin{array}{c}\text { Jumlah } \\
\text { n }\end{array}$} & \multirow{3}{*}{ p-value } & \multirow{3}{*}{ PR $(95 \%$ CI $)$} \\
\hline & \multicolumn{2}{|c|}{ Ada } & \multicolumn{2}{|c|}{ Tidak Ada } & & & \\
\hline & $\mathrm{n}$ & $\%$ & $\mathrm{n}$ & $\%$ & & & \\
\hline$>\mathrm{NAB}$ & 8 & 42,1 & 11 & 57,9 & 19 & 0,037 & 1,723 \\
\hline$\leq \mathrm{NAB}$ & 37 & 72,5 & 14 & 27,5 & 51 & & $(0,991-2,997)$ \\
\hline
\end{tabular}

Berdasarkan tabel 5, hasil analisis hubungan antara whole body vibration (WBV) dengan keluhan low back pain (LBP) diperoleh bahwa ada sebanyak 8 $(42,1 \%)$ operator alat berat yang terpapar whole body vibration (WBV) melebihi NAB yang mengalami keluhan low back pain (LBP). Sedangkan diantara operator alat berat yang terpapar whole body vibration (WBV) kurang dari NAB, ada 37 $(72,5 \%)$ yang mengalami keluhan low back pain (LBP). Hasil uji statistik diperoleh nilai $p$-value $=0,037$ maka dapat disimpulkan ada hubungan yang signifikan antara whole body vibration (WBV) dengan keluhan low back pain (LBP). Dari hasil analisis diperoleh pula nilai $\mathrm{PR}=0,580$, artinya operator alat berat yang terpapar whole body vibration (WBV) melebihi NAB mempunyai peluang untuk mengalami keluhan low back pain (LBP) 0,580 kali lebih besar dibandingkan dengan operator alat berat yang terpapar whole body vibration (WBV) kurang dari NAB.

Tabel 6 Hubungan Umur dengan Keluhan Low Back Pain (LBP) pada Operator Alat Berat di PT. X

\begin{tabular}{|c|c|c|c|c|c|c|c|}
\hline \multirow{3}{*}{ Umur } & \multicolumn{4}{|c|}{ Keluhan Low Back Pain } & \multirow{3}{*}{$\begin{array}{c}\text { Jumlah } \\
\mathbf{N}\end{array}$} & \multirow{3}{*}{ p-value } & \multirow{3}{*}{ PR $(95 \%$ CI $)$} \\
\hline & \multicolumn{2}{|c|}{ Ada } & \multicolumn{2}{|c|}{ Tidak Ada } & & & \\
\hline & $\mathrm{N}$ & $\%$ & $\mathrm{n}$ & $\%$ & & & \\
\hline$>35$ tahun & 34 & 85 & 6 & 15 & 40 & & 2,318 \\
\hline$\leq 35$ tahun & 11 & 36.7 & 19 & 63.3 & 30 & 0,000 & $(1,423-3,776)$ \\
\hline
\end{tabular}

Berdasarkan tabel 6, hasil analisis hubungan antara umur dengan keluhan low back pain (LBP) diperoleh bahwa ada sebanyak $34(85 \%)$ operator yang berumur $>35$ tahun mengalami keluhan low back pain (LBP). Sedangkan diantara operator yang berumur $\leq 35$ tahun, ada $11(36,7 \%)$ yang mengalami keluhan low back pain (LBP). Hasil uji statistik diperoleh $p$-value $=0,000$ maka dapat disimpulkan ada 
hubungan yang signifikan antara umur dengan keluhan low back pain (LBP). Dari hasil analisis diperoleh pula nilai PR $=2,318$, artinya operator yang berumur $>$ 35 tahun mempunyai peluang 2,318 kali

Tabel 7 Hubungan Masa Kerja dengan Keluhan Low Back Pain (LBP) pada Operator Alat Berat di PT. X

\begin{tabular}{ccccccccc}
\hline \multirow{2}{*}{ Masa Kerja } & \multicolumn{2}{c}{ Keluhan Low Back Pain } & Jumlah & \multirow{2}{*}{-value } & \multirow{2}{*}{ PR (95\% CI) } \\
\cline { 2 - 5 } & \multicolumn{2}{c}{ Ada } & \multicolumn{2}{c}{ Tidak Ada } & N & & \\
\hline$>5$ tahun & 42 & 72,4 & 16 & 27,6 & 58 & & \\
$\leq 5$ tahun & 3 & 25 & 9 & 75 & 12 & 0,006 & 2,897 \\
& & & & & & & & $(1,073-7,817)$ \\
\hline
\end{tabular}

Berdasarkan tabel 7, hasil analisis hubungan antara masa kerja dengan keluhan low back pain (LBP) diperoleh bahwa ada sebanyak $42(72,4 \%)$ operator alat berat dengan masa kerja $>5$ tahun yang mengalami keluhan low back pain (LBP). Sedangkan diantara operator alat berat dengan masa kerja $\leq 5$ tahun, ada 3 (25\%) yang mengalami keluhan low back pain (LBP). Hasil uji statistik diperoleh lebih besar untuk mengalami keluhan low back pain (LBP) dibandingkan dengan operator alat berat yang berumur $\leq 35$ tahun.

Tabel 8 Hubungan Indeks Massa Tubuh dengan Keluhan Low Back Pain (LBP) pada Operator Alat Berat di PT. X

\begin{tabular}{|c|c|c|c|c|c|c|c|}
\hline \multirow{3}{*}{$\begin{array}{c}\text { Indeks } \\
\text { Massa } \\
\text { Tubuh }\end{array}$} & \multicolumn{4}{|c|}{ Keluhan Low Back Pain } & \multirow{3}{*}{$\begin{array}{c}\text { Jumlah } \\
\mathbf{n}\end{array}$} & \multirow{3}{*}{ p-value } & \multirow{3}{*}{$\begin{array}{c}\text { PR }(95 \% \\
\text { CI) }\end{array}$} \\
\hline & \multicolumn{2}{|c|}{ Ada } & \multicolumn{2}{|c|}{ Tidak Ada } & & & \\
\hline & $\mathrm{n}$ & $\%$ & $\mathrm{~N}$ & $\%$ & & & \\
\hline $\begin{array}{l}\text { Overweight } \\
(>23)\end{array}$ & 26 & 63,4 & 15 & 36,6 & 41 & 1,000 & 0,969 \\
\hline $\begin{array}{c}\text { Normoweight } \\
\quad(\leq 23)\end{array}$ & 19 & 65,5 & 10 & 34,5 & 29 & & $(0,681-1,376)$ \\
\hline
\end{tabular}

Berdasarkan tabel 8, hasil analisis dengan keluhan low back pain (LBP) hubungan antara indeks massa tubuh diperoleh bahwa ada sebanyak $26(63,4 \%)$ 
operator alat berat yang overweight yang mengalami keluhan low back pain (LBP). Sedangkan diantara operator alat berat yang normoweight, ada 19 (65,5\%)yang mengalami keluhan low back pain (LBP).
Hasil uji statistik diperoleh nilai $p$-value $=$ $1,000>0,05$ maka dapat disimpulkan tidak ada hubungan yang signifikan antara indeks massa tubuh dengan keluhan low back pain (LBP).

Tabel 9 Hubungan Aktivitas fisik dengan Keluhan Low Back Pain (LBP) pada Operator Alat Berat di PT. X

\begin{tabular}{|c|c|c|c|c|c|c|c|}
\hline \multirow{3}{*}{$\begin{array}{l}\text { Aktivitas } \\
\text { fisik }\end{array}$} & \multicolumn{4}{|c|}{ Keluhan Low Back Pain } & \multirow{3}{*}{$\begin{array}{c}\text { Jumlah } \\
\mathbf{N}\end{array}$} & \multirow{3}{*}{$p$-value } & \multirow{3}{*}{ PR $(95 \%$ CI $)$} \\
\hline & \multicolumn{2}{|c|}{ Ada } & \multicolumn{2}{|c|}{ Tidak Ada } & & & \\
\hline & $\mathrm{N}$ & $\%$ & $\mathrm{~N}$ & $\%$ & & & \\
\hline $\begin{array}{c}\text { Kurang } \\
(<150 \text { menit/mg })\end{array}$ & 35 & 61,4 & 22 & 38,6 & 57 & 0,353 & $\begin{array}{c}0,798 \\
(0,556-1,146)\end{array}$ \\
\hline $\begin{array}{c}\text { Cukup } \\
(\geq 150 \mathrm{menit} / \mathrm{mg})\end{array}$ & 10 & 76,9 & 3 & 23,1 & 13 & & \\
\hline
\end{tabular}

Berdasarkan tabel 9, hasil analisis hubungan antara aktivitas fisik dengan keluhan low back pain (LBP) diperoleh bahwa ada sebanyak $35(61,4 \%)$ operator alat berat dengan aktivitas fisik kurang yang mengalami keluhan low back pain (LBP). Sedangkan diantara operator alat berat dengan aktivitas fisik cukup, ada 10 $(76,9 \%)$ yang mengalami keluhan low back pain (LBP). Hasil uji statistik diperoleh nilai $p$-value $=0,353>0,05$ maka dapat disimpulkan tidak ada hubungan yang signifikan antara aktivitas fisik dengan keluhan low back pain (LBP).

\section{Analisis Multivariat}

Pemilihan variabel kandidat multivariat dengan menggunakan uji (chisquare) melalui tahap seleksi bivariat dan kemudian mengunakan metode ENTER sehingga didapatkan model akhir regresi logistik ganda. 
Tabel 10 Model Akhir Regresi Logistik

\begin{tabular}{lccccc}
\hline \multicolumn{1}{c}{ Variabel } & B & S.E. & Sig. & Exp(B) & 95\% C.I.for EXP(B) \\
\hline Whole Body Vibration & 1.749 & 0.739 & 0.018 & 5.750 & $1.351-24.475$ \\
(WBV) & 2.107 & 0.694 & 0.002 & 8.221 & $2.111-32.013$ \\
Umur & 1.540 & 0.917 & 0.093 & 4.663 & $0.772-28.159$ \\
Masa Kerja & 0.366 & 0.642 & 0.568 & 1.442 & $0.410-5.074$ \\
Indeks Massa Tubuh & -1.127 & 0.940 & 0.230 & 0.324 & $0.051-2.044$ \\
Aktivitas fisik & -2.218 & 1.176 & 0.059 & 0.109 & \\
\hline Constant & & & & & \\
\hline
\end{tabular}

Berdasarkan Tabel 10 diatas menunjukkan bahwa hasil analisis multivariat yang menggunakan regresi logistik, terdapat 2 variabel yang mempengaruhi terjadinya keluhan low back pain (LBP) yaitu variabel whole body vibration (WBV) dan variabel umur. Faktor risiko dari keluhan low back pain (LBP) adalah variabel whole body vibration (WBV) dengan Exp. B 5,750 (p-value 0,018, 95\% CI 1,351 - 24,475), artinya setiap operator alat berat yang terpapar whole body vibaration (WBV) akan mengalami keluhan low back pain (LBP) sebesar 5,750 kali lebih tinggi dibandingkan dengan operator alat berat yang tidak terpapar whole body vibration (WBV) setelah dikontrol variabel masa kerja, indeks massa tubuh dan variabel aktifitas fisik. Serta variabel umur dengan Exp B 8,221 (p-value 0,002, 95\% CI 2,111 $32,013)$, artinya setiap operator alat berat yang berumur > 35 tahun akan mengalami keluhan low back pain (LBP) sebesar 8,221 kali lebih tinggi dibandingkan dengan operator alat berat yang berumur $\leq 35$ tahun.

\section{PEMBAHASAN}

Hubungan Whole Body Vibration (WBV) dengan Keluhan Low Back Pain (LBP) pada Operator Alat Berat di PT. X

Hasil uji bivariat pada penelitian ini menunjukkan bahwa ada hubungan yang signifikan antara whole body vibration (WBV) dengan keluhan low back pain (LBP) pada operator alat berat di PT. X ( $p=0,037$ ). Proporsi pekerja yang terpapar melebihi $\mathrm{NAB}$ dengan keluhan low back pain (LBP) hanya sebesar $42,1 \%$. Sedangkan proporsi pekerja yang terpapar kurang dari NAB dengan keluhan low back pain (LBP) cukup tinggi yaitu sebesar 72,5\%. Hal ini menunjukkan bahwa whole body vibration (WBV) tidak mempengaruhi terjadinya keluhan low back pain (LBP). Akan tetapi berdasarkan hasil pengamatan peneliti terdapat faktor-faktor pendukung lain yang 
dapat mempengaruhi terjadinya keluhan low back pain (LBP) berupa rentang waktu kerja yang terlalu lama yang menyebabkan pekerja terpapar getaran secara terus-menerus, waktu istirahat yang kurang, posisi kerja yang statis dan canggung, serta seringnya kerja lembur yang dilakukan oleh para pekerja yaitu lebih dari 3 jam/hari dan 14 jam dalam satu minggu.

Paparan yang berkepanjangan terhadap whole body vibration (WBV) berdampak buruk pada berbagai sistem jaringan tubuh dan beberapa literature telah menekankan bahwa low back pain (LBP) sebagai konsekuensi utama dari terjadinya paparan whole body vibration (WBV) yang berkepanjangan pada pembalap professional (Burström, Nilsson and Wahlström, 2015). Studi laboratorium menunjukkan bahwa paparan terhadap whole body vibration (WBV) meningkatkan kelelahan fisik dan kelelahan mental, yang merupakan masalah umum yang dihadapi oleh pembalap professional (Du et al., 2018).

Hasil analisis multivariat regresi binary logistik pada permodelan akhir penelitian ini mengindikasikan faktor risiko paling dominan terhadap keluhan low back pain (LBP) adalah whole body vibration (WBV) ( $\mathrm{p}=0,018<0,05)$. Hal ini sejalan dengan penelitian yang dilakukan oleh Burström,
Nilsson and Wahlström (2015) yang menunjukkan bahwa paparan whole body vibration (WBV) berhubungan dengan terjadinya peningkatan prevalensi low back pain (LBP). Pekerja yang terpapar dengan tingkat getaran yang tinggi 1,5 kali lebih berisiko untuk terjadinya low back pain (LBP) dibandingkan dengan pekerja yang terpapar tingkat getaran yang rendah. Sedangkan dalam penelitian kohort prospektif yang dilakukan oleh Bovenzi et al. (2014), pengukuran beban tulang belakang internal merupakan prediktor yang lebih baik untuk terjadinya gejala low back pain (LBP) dibandingkan dengan pengukuran paparan getaran harian.

Penelitian yang dilakukan oleh Kim et al (2016) juga menunjukkan bahwa terdapat hubungan yang kuat antara whole body vibration $(\mathrm{WBV})(\mathrm{p}=0,03)$ terhadap keluhan musculoskeletal khususnya low back pain (LBP) (72,5\%). Begitu pula dengan penelitian yang dilakukan oleh Taylor, Morgan and Mansfield (2014) menunjukkan bahwa paparan whole body vibration (WBV) terhadap operator mesin pertanian merupakan faktor risiko untuk terjadinya low back pain (LBP). Didukung dengan penelitian yang dilakukan oleh Mayton et al (2017) yang melaporkan bahwa whole body vibration (WBV) adalah faktor yang 
berkontribusi dalam perkembangan gangguan musculoskeletal, low back pain (LBP), kelelahan dan mempengaruhi kesehatan serta kinerja dari para pekerja.

Beberapa keluhan kesehatan dan gejala yang disebabkan oleh paparan getaran terhadap sistem organ yaitu sistem ortopedi dan neurologis (rasa sakit yang dilokalisasi atau memancar, tidak nyaman, mati rasa, kesemutan, kehilangan perasaan dan control otot di tulang belakang atau ekstremitas), sistem gastrointestinal (mual, muntah, gangguan pencernaan, nyeri panggul), organ reproduksi wanita (rasa sakit yang dilokalisasi, menstruasi yang tidak teratur), prostat (sensasi terbakar, pembesaran prostat) dan vena perifer berupa vertigo (Taylor and Johanning, 2015).

Hubungan Umur dengan Keluhan Low Back Pain (LBP) pada Operator Alat Berat di PT. X

Hasil uji bivariat pada penelitian ini menunjukkan bahwa ada hubungan yang signifikan antara umur dengan keluhan low back pain (LBP) pada operator alat berat di PT. $X(p=0,000)$. Proporsi pekerja yang berumur lebih dari 35 tahun dengan keluhan low back pain (LBP) cukup tinggi yaitu sebesar $85 \%$ dibandingkan dengan proporsi pekerja yang berumur kurang dari 35 tahun yang mengalami keluhan low back pain (LBP) hanya sebesar $36,7 \%$.
Hasil analisis multivariat regresi binary logistik pada permodelan akhir penelitian ini menunjukkan ada hubungan yang signifikan antara umur dengan keluhan low back pain (LBP) pada operator alat berat di PT. X dengan $p$-value $=0,002$. Sejalan dengan penelitian yang dilakukan Med et al (2009) yang menunjukkan bahwa ada hubungan yang signifikan antara umur dengan low back pain (LBP) $(\mathrm{p}=0,011)$. Meningkatnya usia akan terjadi degenerasi pada tulang dan keadaan ini mulai terjadi saat seseorang berusia 30 tahun. Usia 30 tahun terjadi degenerasi yang berupa kerusakan jaringan, penggantian jaringan menjadi jaringan parut, pengurangan cairan. Hal tersebut menyebabkan stabilitas pada tulang dan otot menjadi berkurang. Semakin tua seseorang, semakin tinggi risiko orang tersebut mengalami penurunan elastisitas pada tulang yang menjadi pemicu timbulnya gejala low back pain (LBP). Akibat proses tersebut terbentuk jaringan parut di diskus invertebrate, jumlah cairan diantara sendi berkurang dan ruang diskus mendangkal secara permanen. Akibatnya segmen spinal akan kehilangan stabilitasnya. Pendangkalan di ruang diskus akan mengurangi kemampuan tulang belakang terutama daerah lumbal untuk menahan beban menjadi berkurang. Seharusnya vertebra lumbal 
mampu menahan beban dan pergerakan tubuh akan menyebabkan keluhan low back pain (LBP) (Jatmikawati, 2006).

Hubungan Masa Kerja dengan Keluhan Low Back Pain (LBP) pada Operator Alat Berat di PT. X

Berdasarkan hasil uji bivariat pada penelitian ini menunjukkan bahwa ada hubungan yang signifikan antara masa kerja dengan keluhan low back pain (LBP) pada operator alat berat di PT. X $(\mathrm{p}=0,006)$. Proporsi pekerja dengan masa kerja lebih dari 5 tahun yang mengalami keluhan low back pain (LBP) adalah 72,4\%. Sedangkan proporsi pekerja dengan masa kerja kurang dari 5 tahun dengan keluhan low back pain (LBP) yaitu sebesar 25\%. Berdasarkan hasil pengamatan peneliti, operator alat berat dengan masa kerja terlama adalah 30 tahun dan operator alat berat dengan masa kerja tersingkat adalah 2 tahun.

Masa kerja adalah panjangnya waktu terhitung mulai pertama kali pekerja masuk kerja hingga saat penelitian berlangsung. Musculoskeletal disorders atau low back pain (LBP) merupakan penyakit kronis yang membutuhkan waktu lama untuk berkembang dan bermanifestasi. Jadi semakin lama waktu bekerja atau semakin lama seseorang terpajan faktor risiko low back pain (LBP) maka akan semakin besar pula risiko untuk mengalami low back pain
(LBP) (Guo et al., 2004). Disamping itu, Hasyim (2000) menyatakan bahwa masa kerja menyebabkan beban statik yang terusmenerus apabila pekerja tidak memperhatikan faktor-faktor ergonomik akan lebih mudah menimbulkan keluhan low back pain (LBP). Masa kerja yang lama dapat berpengaruh terhadap low back pain (LBP) karena merupakan akumulasi pembebanan pada tulang belakang akibat aktivitas seharihari.

Hasil analisis multivariat regresi binary logistik pada permodelan akhir penelitian ini menunjukkan bahwa masa kerja merupakan faktor confounding dengan p-value $=0,093$. Sejalan dengan penelitian yang dilakukan oleh Kreshnanda (2016) menunjukkan bahwa ada hubungan yang signifikan antara masa kerja dengan keluhan low back pain (LBP). Begitu pula dengan penelitian yang dilakukan oleh Umami (2013) yang menunjukkan bahwa pekerja yang banyak mengalami keluhan low back pain (LBP) adalah pekerja yang memiliki masa kerja >10 tahun dibandingkan dengan mereka dengan masa kerja <5 tahun ataupun 5-10 tahun. Serta sebuah studi yang dilakukan oleh Suharto (2005) menunjukkan bahwa seseorang yang bekerja lebih dari 5 tahun meningkatkan risiko terjadinya low back pain (LBP) dibandingkan dengan pekerja dengan 
masa kerja <5 tahun, dimana paparan mengakibatkan rongga diskus menyempit secara permanen dan juga mengakibatkan degenerasi tulang belakang yang akan menyebabkan low back pain chronic.

\section{Hubungan Indeks Massa Tubuh dengan Keluhan Low Back Pain (LBP) pada Operator Alat Berat di PT. X}

Berdasarkan hasil uji bivariat pada penelitian ini menunjukkan bahwa tidak ada hubungan yang signifikan antara indeks massa tubuh dengan keluhan low back pain (LBP) pada operator alat berat di PT. X ( $\mathrm{p}=$ 1,000). Proporsi pekerja dengan indeks massa tubuh overweight dengan keluhan low back pain (LBP) adalah sebesar 63,4 \% sedangkan proporsi pekerja dengan indeks massa tubuh normal yang mengalami keluhan low back pain (LBP) adalah 65,5\%. Hasil analisis multivariat regresi binary logistik pada permodelan akhir penelitian ini menunjukkan indeks massa tubuh merupakan faktor confounding dengan $p$-value $=0,568$. Sejalan dengan penelitian yang dilakukan oleh Murtezani et al ( 2011) menunjukkan bahwa tidak ada hubungan yang signifikan antara berat badan dan tinggi badan dengan angka prevalensi low back pain (LBP). Sejalan dengan itu penelitian yang dilakukan oleh Yücel and Torun (2016) menunjukkan bahwa low back pain (LBP) tidak terpengaruh oleh nilai indeks massa tubuh karena berada dalam interval normal. Namun, hubungan antara perubahan berat badan dalam enam bulan terakhir dan low back pain (LBP) ditemukan menjadi signifikan secara statistik. Begitu pula dengan penelitian yang dilakukan oleh $\mathrm{Li}$ et al ( 2012) menunjukkan bahwa tidak ada hubungan antara indeks massa tubuh dengan low back pain (LBP). Meskipun beberapa studi mengidentifikasikan korelasi yang lemah. Namun ada bukti yang cukup untuk mendirikan sebuah hubungan kausal langsung antara obesitas dengan low back pain (LBP). Obesitas dilihat sebagai faktor penting dalam patogenesis low back pain (LBP) (Gasibat et al., 2017). Hubungan antara obesitas dan low back pain (LBP) dapat menjadi faktor penyebab yaitu obesitas dapat meningkatkan beban mekanik pada tulang belakang dengan menyebabkan gaya tekan yang lebih tinggi atau peningkatan gesekan pada struktur tulang belakang lumbar selama melakukan berbagai aktfitas.Obesitas lebih mudah terkena cedera yang tidak disengaja. Obesitas dapat menyebabkan low back pain (LBP) melalui peradangan kronik sistemik. Obesitas dikaitkan dengan peningkatan produksi sitokin dan reaktan fase akut dan dengan aktivasi jalur pro-inflamasi (Hameed, 2013). 


\section{Hubungan Aktivitas fisik dengan Keluhan Low Back Pain (LBP) pada Operator Alat Berat di PT. X}

Hasil uji bivariat pada penelitian ini menunjukkan bahwa tidak ada hubungan yang signifikan antara aktivitas fisik dengan keluhan low back pain (LBP) pada operator alat berat di PT. X $(p=0,353>0,05)$. Hasil analisis multivariat regresi binary logistik pada permodelan akhir penelitian ini menunjukkan aktivitas fisik sebagai faktor confounding dengan p-value 0,227.

Penelitian yang dilakukan oleh Wong et al (2010) menunjukkan bahwa tidak ada hubungan yang signifikan antara aktivitas fisik dengan low back pain (LBP) ( $>00,005)$. Sedangkan penelitian yang dilakukan oleh Murtezani et al ( 2011) menunjukkan bahwa terdapat hubungan yang signifikan antara aktifitas fisik (berjalan, bersepeda, berenang dan lain-lain) dengan prevalensi low back pain $(\mathrm{LBP})(\mathrm{p}=0,03)$ dan ada perbedaan yang signifikan antara aktifitas fisik dengan kategori sering dengan tingkat keparahan low back pain $(\mathrm{LBP})(\mathrm{p}=0,01)$. Sejalan dengan itu penelitian yang dilakukan oleh Abledu, Offei and Abledu (2014) pada pengemudi minibus menunjukkan bahwa tingginya prevalensi work related musculoskeletal disorders $(78,4 \%)$ terkait dengan kurangnya aktifitas fisik dari para pengemudi minibus di Accra Metropolis. Kurangnya aktivitas fisik dapat menurunkan suplai oksigen ke dalam otot sehingga dapat menyebabkan adanya keluhan otot. Otot yang lemah terutama pada daerah perut tidak mampu menyokong punggung secara maksimal. Semakin jarang seseorang berolahraga, semakin tinggi pula tingkat keluhan otot yang dirasakan.

Salah satu pilar penanganan low back pain (LBP) adalah dengan exercise atau latihan untuk otot perut dan punggung. Bila otot abdomen dan otot punggung kita kuat, itu akan membantu kita dalam menjaga postur tubuh yang baik dan menjaga agar tulang belakang senantiasa berada pada lokasi yang tepat.

\section{KESIMPULAN}

1. Angka keluhan low back pain (LBP) pada operator alat berat di PT. X yaitu yang mengalami keluhan low back pain (LBP) $(64,3 \%)$ dan yang tidak mengalami keluhan low back pain (LBP) $(35,7 \%)$.

2. Angka paparan whole body vibration (WBV) pada operator alat berat di PT. X yaitu sebesar $0,543 \mathrm{~m} / \mathrm{s}^{2}$.

3. Terdapat hubungan yang signifikan antara whole body vibration (WBV), umur dan masa kerja, dengan keluhan low back pain (LBP) pada operator alat berat di PT. X.

4. Tidak ada hubungan yang signifikan antara IMT dan aktivitas fisik dengan 
keluhan low back pain (LBP) pada operator alat berat di PT. X.

\section{SARAN}

1. Membuat program peniaian risiko dan mitigasi, manajemen keluhan musculoskeletal, pelatihan LBP dan intervensi macroergonomicyang terintegrasi ke dalam sistem manajemen kesehatan kerja perusahaan.

2. Memberikan pelatihan atau training pada pekerja mengenai risiko pekerjaan dan tata cara bekerja yang sesuai dengan prinsip ergonomic.

3. Memasang peredam getaran atau back support pada kursi alat berat yang berfungsi untuk mengurangi tingkat getaran yang timbul.

\section{DAFTAR PUSTAKA}

Al-Otaibi, S. 2015. Prevention Of Occupational Back Pain. Journal Of Family And Community Medicine. Vol 22(2) : p. 73. doi: 10.4103/22308229.155370 .

Bovenzi, M., Schust, M., and Mauro, M. 2017. An Overview Of Low Back Pain And Occupational Exposures To Whole-Body Vibration And Mechanical Shocks. La Medicina Del Lavoro. Vol 108(6) : pp. 419-433. doi: 10.23749/Mdl.V108i6.6639.

Bovenzi, M., Schust, M., Menzel, G., Prodi, A., and Mauro.,M. 2014. Relationships of Low Back Outcomes to Internal Spinal Load: A Prospective Cohort Study Of Professional Drivers. Vol 5(10) : pp 120-129. doi: 10.1007/S00420-014-0976-Z.
Burström, L., Nilsson, T., and Wahlström, J. 2015. Whole-Body Vibration and The Risk of Low Back Pain and Sciatica : A Systematic Review and Meta-Analysis. International Archives of Occupational and Environmental Health. Vol 88(4) : pp. 403-418. doi: 10.1007/S00420014-0971-4.

COWI. 2015. Evaluation of The Practical Implementation of The Eu Occupational Safety And Health $(\mathrm{OSH})$ Directives In Eu Member States. Page. 416.

Health and Safety Executive. 2017. WorkRelated Musculoskeletal Disorders (Wrmsds) Statistics In Great Britain 2017. Diakses pada tgl 20 Maret 2018 di www.HSE.gov.uk/Statistics/.

Janwantanakul, $\quad$ P., $\quad$ Pensri, $\quad$ P., Jiamjarasrangsri, $\quad$ V.,and Singsongsook, T. 2008. Prevalence of Self-Reported Musculoskeletal Symptoms Among Office Workers. Occupational Medicine. Vol 58(6) : pp. 436-438. doi: 10.1093/Occmed/Kqn072.

Kittusamy, N. K., and Buchholz, B. 2004. Whole-Body Vibration And Postural Stress Among Operators Of Construction Equipment: A Literature Review. Journal Of Safety Research. Vol 35(3) : pp. 255-261. doi: 10.1016/J.Jsr.2004.03.014.

Kim, J. H., Zigman, M., Aulck, L.S.,Ibbtson, J.A., Dennerlein, J.T., and Johnson, P.W. 2016. Whole Body Vibration Exposures And Health Status Among Professional Truck Drivers: A CrossSectional Analysis. pp. 1-13. doi: 10.1093/Annhyg/Mew040.

Mcbride, D., Paulin, S., Herbison, G.P., Waite, D., and Bagheri, N. 2014. Low Back And Neck Pain In Locomotive Engineers Exposed To Whole-Body 
Vibration. Journal Environmental and Occupational Health. Vol.69 : pp. 3741. doi:

10.1080/19338244.2013.771246.

Mitchell, T., O'Sullivan, P.B., Burnett, A.F., Straker, L., and Rudd, C. 2008. Low Back Pain Characteristics From Undergraduate Student To Working Nurse In Australia: A Cross-Sectional Survey. International Journal of Nursing Studies. Vol 45(11) : pp. 1636-1644. doi: 10.1016/J.Ijnurstu.2008.03.001.

Monteiro, Silvia., Alexandre, M.C., Ilmarinen, J.,and Rodrigues, M. 2009. Work Ability And Musculoskeletal Disorders Among Workers From A Public Health Institution. International Journal Of Occupational Safety And Ergonomics. Vol 15(3) : pp. 319-324. doi:

10.1080/10803548.2009.11076813.

Murtezani, A., Ibraimi, Z., Sllamniku, S., Osmani, T.,and Sherifi, S. 2011. Prevalence and Risk Factors For Low Back Pain In Industrial Workers. Vol 53(4) : pp. 68-74. Doi: 10.2478/V10153-011-0060-3.

Nazerian, R., Korhan, O., and Shakeri, E. 2018. Work Related Musculoskeletal Discomfort Among Heavy Truck Drivers. International Journal of Occupational Safety And Ergnomics. Taylor \& Francis. Vol 0(0) : pp. 1-22. Doi: 10.1080/10803548.2018.1433107.

Occupational Safety and Health Administration .2007. Ergonomic Guidelines For Manual Material Handling. Dhhs (NIOSH) Publication. Vol 6 (2) pp. 131. doi: 10.1017/Cbo9781107415324.004

Spiekermann, J., Kurz, S., and Leucht, F. 2013. Prevalence Of Sleep Deprivation
In Patients With Chronic Neck And Back Pain : A Retrospective Evaluation Of 1016 Patients. Vol. 16(5) : pp. 1-6.

Thomas, E. N., Pers, Y. M., Mercier, G., Cambiere, J. P., Frasson, N., Ster, F., Hérisson, C., and Blotman, F. 2010. The Importance Of Fear, Beliefs, Catastrophizing And Kinesiophobia In Chronic Low Back Pain Rehabilitation. Journal Annals Of Physical And Rehabilitation Medicine. Vol 53(1): pp. 3-14. doi: 10.1016/J.Rehab.2009.11.002.

Tüchsen, F, Feveile, H., Christensen, K., and Krause, N. 2010. The Impact Of SelfReported Exposure To Whole-BodyVibrations On The Risk Of Disability Pension Among Men: A 15 Year Prospective Study. Journal Bmc Public Health. Vol 10 : pp. 2-7. doi: 10.1186/1471-2458-10-305.

Viruet, H. B. 2003. Musculoskeletal Disorders Among Forklift Operators: A Review And Critical Appraisal For Safety Improvement. Journal Engineering.

Waters, T., Genaidy, A., Viruet, H.B.,and Makola, M. 2008. The Impact Of Operating Heavy Equipment Vehicles On Lower Back Disorders. Journal Ergonomics. Vol 51(5) : pp. 602-636. doi: 10.1080/00140130701779197.

Yücel, H., and Torun, P. 2016. Incidence And Risk Factors Of Low Back Pain In Students Studying At A Health University. Journal Beizmalem Science. Vol 5(2) : pp. 12-18. doi: 10.14235/Bs.2016.6 
